\title{
A study on the evaluations of emission factors and uncertainty ranges for methane and nitrous oxide from combined-cycle power plant in Korea
}

\author{
Seehyung Lee • Jinsu Kim • Jeongwoo Lee • \\ Seongho Lee $\cdot$ Eui-Chan Jeon
}

Received: 11 February 2012 / Accepted: 27 August 2012 / Published online: 22 September 2012

(C) The Author(s) 2012. This article is published with open access at Springerlink.com

\begin{abstract}
In this research, in order to develop technology/ country-specific emission factors of methane $\left(\mathrm{CH}_{4}\right)$ and nitrous oxide $\left(\mathrm{N}_{2} \mathrm{O}\right)$, a total of 585 samples from eight gas-fired turbine combined cycle (GTCC) power plants were measured and analyzed. The research found that the emission factor for $\mathrm{CH}_{4}$ stood at " $0.82 \mathrm{~kg} / \mathrm{TJ}$ ", which was an $18 \%$ lower than the emission factor for liquefied natural gas (LNG) GTCC "1 kg/ TJ" presented by Intergovernmental Panel on Climate Change (IPCC). The result was $8 \%$ up when compared with the emission factor of Japan which stands at " $0.75 \mathrm{~kg} / \mathrm{TJ}$ ". The emission factor for $\mathrm{N}_{2} \mathrm{O}$ was " $0.65 \mathrm{~kg} / \mathrm{TJ}$ ", which is significantly lower than " $3 \mathrm{~kg} / \mathrm{TJ}$ " of the emission factor for LNG GTCC presented by IPCC, but over six times higher than the default $\mathrm{N}_{2} \mathrm{O}$ emission factor of LNG. The evaluation of uncertainty was conducted based on the estimated non- $\mathrm{CO}_{2}$ emission factors, and the ranges of uncertainty for $\mathrm{CH}_{4}$ and $\mathrm{N}_{2} \mathrm{O}$ were between -12.96 and $+13.89 \%$, and -11.43 and $+12.86 \%$, respectively, which is significantly lower than uncertainties presented by IPCC. These differences proved that non- $\mathrm{CO}_{2}$ emissions can change depending on combustion
\end{abstract}

Responsible editor: Philippe Garrigues

$\mathrm{S}$. Lee $\cdot$ J. Lee $\cdot \mathrm{S}$. Lee

Department of Earth and Environmental Sciences,

Sejong University,

98 Gunja-dong Gwangjin-gu,

Seoul 143-747, South Korea

J. Kim

Cooperate Course for Climate Change, Sejong University,

98 Gunja-dong Gwangjin-gu,

Seoul 143-747, South Korea

E.-C. Jeon $(\square)$

Department of Environment \& Energy, Sejong University,

98 Gunja-dong Gwangjin-gu,

Seoul 143-747, South Korea

e-mail: ecjeon@sejong.ac.kr technologies; therefore, it is vital to establish country/technology-specific emission factors.

Keywords Greenhouse gas $\cdot$ Methane $\cdot$ Nitrous oxide Emission factor $\cdot$ Non- $\mathrm{CO}_{2} \cdot$ Power plant

\section{Introduction}

In 2009, Korea announced greenhouse gas mitigation commitment to release $30 \%$ less greenhouse gas than the "Business As Usual" level by 2020 (The Ministry of Environment 2010). It also enacted the "Low Carbon Green Growth Act" in 2010, setting legal grounds for regulation of greenhouse gas emissions to achieve the reduction target. And through the enforcement ordinance of the law, it implemented "GHG Target Management" in April 2010, a system that sets and manages greenhouse gas reduction and energy saving targets in large-scale work sites. In August 2010, 460 companies were designated by the government under these circumstances, so that they fall under government control. As of 2007, the companies released 380 million tons of $\mathrm{CO}_{2}$, which accounts for $60 \%$ of the total greenhouse gas emissions in the country. In addition, it established the guidelines for the GHG Target Management in March 2011 (The Ministry of Environment 2011).

Although there is no globally regulated measurable, reportable and verifiable (MRV) system, Annex I countries set a rigorous MRV system at the national level (KIIEP 2009). Also, at the 15th Conference of the Parties, the Copenhagen Accord agreed that Non-Annex I countries should be required to establish their own MRV system and submit a country report every 2 years (UNFCCC 2009). Thus, Non-Annex I countries do not necessarily have to build the same kind of MRV system on the level of Annex I countries, but without an MRV system at the international level, they are highly likely 
not to be recognized in terms of greenhouse gas emission performance among other countries. In that regard, it is meaningful that Korea established a greenhouse gas MRV system.

At this juncture, Korea is in urgent need to secure well-documented data for drawing up a greenhouse gas inventory. Greenhouse gas emissions are characterized by different kinds of emissions, fuel, types of boilers, antipollution facilities, load factors, and other inherent factors. Non- $\mathrm{CO}_{2}$, in particular, is affected by combustion conditions, operational conditions, technological factors, and several other unknown factors (IPCC 2006; WRI/WBCSD 2005). Therefore, the Intergovernmental Panel on Climate Change (IPCC) recommends that each country put a priority on country- or technology-specific emission factors over default emission factors provided by the IPCC in calculating the amount of greenhouse gas emissions (IPCC 2006; Quick and Glick 2000). Despite this, Korea uses the default emission factors provided by that IPCC since it lacks its own research findings. As of 2006, greenhouse gas emissions by the energy sector has taken up $84 \%$ of the total greenhouse gas emissions, $30 \%$ (about $35 \%$ of the total energy sector) of which have gone to the power generation sector. Thus, the country is expected to be enormously affected if greenhouse gas reduction obligation is imposed (Young-sung et al. 2006). In addition, according to long-term emission prospects, greenhouse gas emissions by the power generation sector are expected to reach $35 \%$ of the total greenhouse gas emissions by 2020 . In Korea's case, a standard and system to classify power generation methods, fuel, combined cycle power generation, cogeneration, etc. should first be established, and greenhouse gas emission factors calculated based on that system.

In this regard, this paper analyzed liquefied natural gas (LNG) gas used in combined cycle power plants in Korea, calculating $\mathrm{CH}_{4}$ and $\mathrm{N}_{2} \mathrm{O}$ emission factors by measuring non- $\mathrm{CO}_{2}$ greenhouse gasses.

\section{Research method}

We researched gas-fired combined cycle power plants in Korea using LNG as an energy source among energy industry, accounting for about $24 \%$ of power generation capacity in Korea.

For $\mathrm{CO}_{2}$, emissions can be fairly estimated based on the amount of fuels combusted and the averaged carbon content of fuel because it mainly depend upon the carbon content of the fuel. However, emissions of non- $\mathrm{CO}_{2}$ are influenced by numerous additional factors such as combustion technology and operating conditions.

Therefore, in this study, to identify the emission characteristics of $\mathrm{CH}_{4}$ and $\mathrm{N}_{2} \mathrm{O}$ and develop emission factors from gas-fired turbine combined cycle power plants, eight plants were selected (Table 1).

Sampling method

When taking greenhouse gas samples, this paper used $1 \mathrm{~L}$ Tedlar bags (SKC, USA) as seen in Fig. 1 and applied United States Environmental Protection Agency (EPA 2001) Method 18. In order to reduce errors, we took three samples in succession on every occasion and measured exhaust gas temperature, moisture amount, flow velocity, pressure, and temperature as well (The Ministry of Environment 2004: Wight 1994). This paper took 585 samples from stacks of generators under operation at eight power plants across Korea.

\section{Exhaust gas analysis method}

The concentrations of non- $\mathrm{CO}_{2}$ in exhaust gasses were analyzed by taking samples of exhaust gasses using a Tedlar bag, then analyzing them by ingredient in the laboratory. The quantitative concentration of non- $\mathrm{CO}_{2}$ was measured with gas chromatography (Model CP-3800, Varian, USA). Flame ionization detector (FID) and electrochemical detectors (ECD)

Table 1 The combined cycle power plants investigated in this study (2007. 1. 1.-12. 31.)

\begin{tabular}{lllll}
\hline Power plants (unit) & Generation capacity $(\mathrm{kW})$ & Gross generation $(\mathrm{MWh})$ & Average load $(\mathrm{kW})$ & Peak load $(\mathrm{kW})$ \\
\hline Ilsan & 900,000 & $3,568,156$ & 407,324 & 817,372 \\
Bundang & 900,000 & $3,791,479$ & 432,817 & 933,000 \\
Anyang & 450,000 & $1,646,561$ & 187,964 & 506,000 \\
Bucheon & 450,000 & $1,562,279$ & 178,342 & 500,000 \\
Pyongtaek & 480,000 & 921,916 & 105,242 & 524,000 \\
Seoincheon & $1,800,000$ & $11,012,625$ & $1,257,149$ & $2,070,000$ \\
Sinincheon & $1,800,000$ & $13,004,005$ & $1,484,475$ & $2,028,000$ \\
GS Bugog & 500,750 & $2,810,883$ & 320,877 & 545,555 \\
Total & $7,280,750$ & $38,317,904$ & $4,374,190$ & $7,923,927$ \\
\hline
\end{tabular}

Source: 2008 Statistics of Electric Power in Korea, KEPCO 


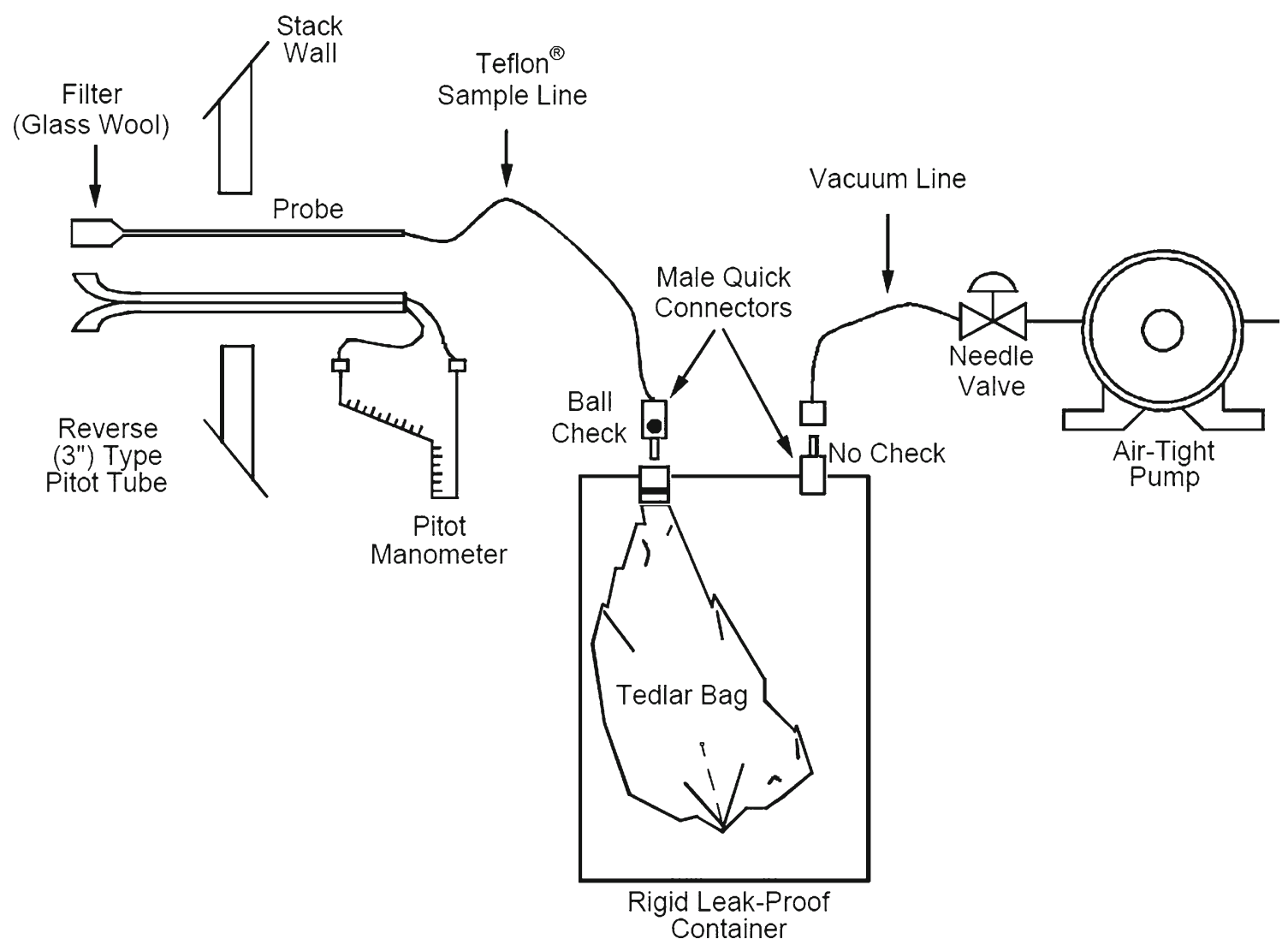

Fig. 1 Diagram of greenhouse gas sampling system

were used as a detector; FID for analyzing $\mathrm{CH}_{4}$ and ECD for $\mathrm{N}_{2} \mathrm{O}$. We used 1 and $3 \mathrm{~m}$ long Porapack QX 80/100 mesh column (stainless steel, external diameter of $3.175 \mathrm{~mm}$, produced by Restek). The temperature of the injector, oven, and detector on the FID was set at 120,70 , and $250{ }^{\circ} \mathrm{C}$, respectively. Additionally, the temperature of the injector, oven, and detector on the ECD was set at 120,70 , and $320^{\circ} \mathrm{C}$, respectively. Ultrapure nitrogen ( $99.9999 \%$ ) was used as carrier gas. When injecting the sample, we used 10-, 6-, and 4-port gasswitching valves to eliminate oxygen and moisture.

In order to carry out quantitative analysis of $\mathrm{CH}_{4}$ and $\mathrm{N}_{2} \mathrm{O}$, we drew up calibration curves of each ingredient in advance and used them in calculating concentrations. The $\mathrm{CH}_{4}$ calibration curve was drawn up by measuring five samples with different concentrations within the range of $0.25-5.0 \mu \mathrm{mol} / \mathrm{mol}$. The $\mathrm{N}_{2} \mathrm{O}$ calibration curve was drawn up by measuring five samples of different concentrations within the range of $0.5-10.0 \mu \mathrm{mol} / \mathrm{mol}$. As a result, the $R^{2}$ value of $\mathrm{CH}_{4}$ and $\mathrm{N}_{2} \mathrm{O}$ was 0.9994 and 0.9992 , respectively, showing high correlation.

Moisture measurement method

Moisture extracting equipment (M-5, Astek Korea) and an electronic scale (Ohaus Adventurer, USA) was used to
Table 2 Repeatability test of concentration analysis using $\mathrm{CH}_{4}$ and $\mathrm{N}_{2} \mathrm{O}$ standard gas

\begin{tabular}{|c|c|c|}
\hline \multirow[t]{2}{*}{ Times } & \multicolumn{2}{|c|}{ Concentration $(\mu \mathrm{mol} / \mathrm{mol})$} \\
\hline & $\mathrm{CH}_{4}$ & $\mathrm{~N}_{2} \mathrm{O}$ \\
\hline Standard $^{\mathrm{a}}$ & 1.1 & 1 \\
\hline 1 & 1.11226 & 1.03801 \\
\hline 2 & 1.10572 & 1.01238 \\
\hline 3 & 1.10449 & 1.01570 \\
\hline 4 & 1.10930 & 0.98851 \\
\hline 5 & 1.09610 & 1.01171 \\
\hline 6 & 1.09919 & 0.98571 \\
\hline 7 & 1.09141 & 0.98551 \\
\hline 8 & 1.09956 & 1.00819 \\
\hline 9 & 1.09746 & 0.98588 \\
\hline 10 & 1.09437 & 0.98644 \\
\hline Mean & 1.10099 & 1.00180 \\
\hline $\mathrm{SD}$ & 0.00673 & 0.01809 \\
\hline RSD (\%) & 0.61160 & 1.80570 \\
\hline SE & 0.00213 & 0.00572 \\
\hline RSE (\%) & 0.19340 & 0.57101 \\
\hline
\end{tabular}

$R S E$ relative standard error

${ }^{\text {a }}$ Origin concentration of standard gas 
Table 3 MDL values of GC/ FID for $\mathrm{CH}_{4}$ and $\mathrm{GC} / \mathrm{ECD}$ for $\mathrm{N}_{2} \mathrm{O}$ in this study

$M D L$ method detection limit

\begin{tabular}{|c|c|c|c|c|}
\hline & \multicolumn{2}{|c|}{$\mathrm{CH}_{4}$ (FID) } & \multicolumn{2}{|c|}{$\mathrm{N}_{2} \mathrm{O}(\mathrm{ECD})$} \\
\hline & Area & Concentration (ppm) & Area & Concentration (ppm) \\
\hline 1 & 536 & 0.0608 & 1,235 & 0.0329 \\
\hline 2 & 612 & 0.0695 & 1,618 & 0.0430 \\
\hline 3 & 952 & 0.1081 & 1,343 & 0.0357 \\
\hline 4 & 861 & 0.0977 & 1,854 & 0.0493 \\
\hline 5 & 508 & 0.0577 & 1,538 & 0.0409 \\
\hline 6 & 742 & 0.0842 & 2,168 & 0.0577 \\
\hline 7 & 672 & 0.0763 & 1,947 & 0.0518 \\
\hline SD & & 0.0187 & & 0.0089 \\
\hline MDL & & 0.0558 & & 0.0280 \\
\hline
\end{tabular}

measure the amount of moisture in the exhaust gas. The temperature of the sample extracting equipment was maintained at $120^{\circ} \mathrm{C}$, while heat rays were quipped in the sample extracting pipe as the moisture in the exhaust gas condensed inside. In order to measure amount of moisture, we filled a cylindrical absorption bottle with anhydrous calcium chloride (Duksan, Korea) and connected it to a sample extracting pipe designed to collect greenhouse gasses. The amount of gas collected was measured to two decimal places (EPA method 4) with an integrating

\begin{tabular}{|c|c|c|c|c|}
\hline \multicolumn{5}{|c|}{ Step 1 (Concentration) } \\
\hline Item & Volume concentration & Mass concentration $\left(\mathrm{CH}_{4}\right)$ & Mass concentration $\left(\mathrm{N}_{2} \mathrm{O}\right)$ & Flow rate \\
\hline Sub-Item & A & B & $\mathrm{C}$ & $\mathrm{D}$ \\
\hline Unit & ppm & $\mathrm{kg} / \mathrm{m}^{3}$ & $\mathrm{~kg} / \mathrm{m}^{3}$ & $\mathrm{~m}^{3} / \mathrm{hr}$ \\
\hline Calculation & & $A \times(16 \div 22.4) \times(273 \div 296)$ & $\mathrm{A} \times(44 \div 22.4) \times(273 \div 296)$ & \\
\hline \multicolumn{5}{|c|}{ Step 2 (Raw Data) } \\
\hline Item & \multicolumn{2}{|c|}{ Lower heating value } & \multicolumn{2}{|c|}{ Fuel consumption } \\
\hline Sub-Item & & $\mathrm{E}$ & \multicolumn{2}{|l|}{$\mathrm{F}$} \\
\hline Unit & \multicolumn{2}{|c|}{$\mathrm{TJ} /$ ton } & \multicolumn{2}{|c|}{ ton $/ \mathrm{hr}$} \\
\hline \multicolumn{5}{|l|}{ Calculation } \\
\hline \multicolumn{5}{|c|}{ Step 3 (Emissions) } \\
\hline Item & \multicolumn{2}{|c|}{$\mathrm{CH}_{4}$ emission } & \multicolumn{2}{|c|}{$\mathrm{N}_{2} \mathrm{O}$ emission } \\
\hline Sub-Item & \multicolumn{2}{|r|}{ G } & \multicolumn{2}{|c|}{$\mathrm{H}$} \\
\hline Unit & \multicolumn{2}{|c|}{$\mathrm{kg} \mathrm{CH}_{4} / \mathrm{hr}$} & \multicolumn{2}{|c|}{$\mathrm{kg} \mathrm{N}{ }_{2} \mathrm{O} / \mathrm{hr}$} \\
\hline Calculation & \multicolumn{2}{|c|}{$\mathrm{B} \times \mathrm{D}$} & \multicolumn{2}{|c|}{$\mathrm{C} \times \mathrm{D}$} \\
\hline \multicolumn{5}{|c|}{ Step 4 (Emission Factor) } \\
\hline Item & \multicolumn{4}{|c|}{ Emission factor } \\
\hline Sub-Item & & I & \multicolumn{2}{|l|}{$\mathrm{J}$} \\
\hline Unit & \multicolumn{2}{|c|}{$\mathrm{t} \mathrm{CH}_{4} / \mathrm{TJ}$} & \multicolumn{2}{|c|}{$\mathrm{t} \mathrm{N}_{2} \mathrm{O} / \mathrm{TJ}$} \\
\hline Calculation & \multicolumn{2}{|c|}{$G \div(E x F) \div 10^{3}$} & \multicolumn{2}{|c|}{$\mathrm{H} \div(\mathrm{ExF}) \div 10^{3}$} \\
\hline
\end{tabular}

Fig. 2 Calculation work-sheet to get non-CO2 emission factor by exhaust gas analysis in this study 
Table 4 Non- $\mathrm{CO}_{2}$ concentration from stacks in the combined cycle power plants

\begin{tabular}{|c|c|c|c|c|}
\hline \multirow[t]{2}{*}{ Plants } & \multirow[t]{2}{*}{ Capacity (MW) } & \multicolumn{2}{|c|}{ Concentration (ppm) } & \multirow[t]{2}{*}{ Samples } \\
\hline & & $\mathrm{CH}_{4}$ & $\mathrm{~N}_{2} \mathrm{O}$ & \\
\hline A & $\geq 100$ & 2.33 & 0.55 & Average of 90 samples \\
\hline B & $\geq 77$ & 1.42 & 0.27 & Average of 105 samples \\
\hline $\mathrm{C}$ & $\geq 75$ & 1.53 & 0.36 & Average of 30 samples \\
\hline $\mathrm{D}$ & $\geq 100$ & 2.24 & 0.41 & Average of 45 samples \\
\hline $\mathrm{E}$ & $\geq 80$ & 1.56 & 0.43 & Average of 45 samples \\
\hline $\mathrm{F}$ & $\geq 75$ & 2.06 & 0.47 & Average of 30 samples \\
\hline G & $\geq 150$ & 2.12 & 0.49 & Average of 120 samples \\
\hline $\mathrm{H}$ & $\geq 160$ & 2.08 & 0.45 & Average of 120 samples \\
\hline Max & & 2.33 & 0.55 & \\
\hline Min & & 1.42 & 0.27 & \\
\hline
\end{tabular}

flow meter attached to the moisture extracting equipment. After collecting the sample, we closed the bottle with a stopper and measured the weight. Then, we calculated the moisture amount in the exhaust gas by applying the weight difference of the bottle before and after collecting the sample, flux collected, and gas temperature.

\section{Quality control of analyzing equipment (QA/AC)}

To confirm the reproducibility of exhaust gas, for $\mathrm{CH}_{4}$ we analyzed the standard gas (RIGAS, Korea) of $1.1 \mu \mathrm{mol} / \mathrm{mol}$ concentration 10 times repetitively. As for $\mathrm{N}_{2} \mathrm{O}$, we analyzed the standard gas (RIGAS) of $1.0 \mu \mathrm{mol} / \mathrm{mol} 10$ times repetitively. The results of reproducibility analysis are presented in Table 2. $\mathrm{CH}_{4}$ and $\mathrm{N}_{2} \mathrm{O}$ showed excellent reproducibility with $0.19340 \%$ and $0.57101 \%$ relative standard error, respectively. The method detection limit of $\mathrm{CH}_{4}$ and $\mathrm{N}_{2} \mathrm{O}$ were 0.0558 and $0.0280 \mathrm{ppm}$, which are indicated on FID and ECD (see Table 3).
Calculation method of emission factor of non- $\mathrm{CO}_{2}$ emissions

In the case of $\mathrm{CO}_{2}$, element analysis of fuel produces a highly reliable emission factor. However, the emission characteristics of non- $\mathrm{CO}_{2}$ differ depending on combustion conditions, such as combustion technology. Therefore, it is difficult to use the emission factor produced from fuel analysis (IPCC 2006) as a representative value. Thus, this paper measured the emission gas concentration of power plants to calculate the non- $\mathrm{CO}_{2}$ emission factor. The work sheet (see Fig. 2) for calculating the emission factor through actual measurements consists of four steps. First is entering the non- $\mathrm{CO}_{2}$ concentration and flux, and conducting unit conversion to calculate the emission factor. Second is standardizing the energy unit of the fuel consumed. The third step is entering the amount of fuel consumed, as well as the electricity and heat produced. For the fourth step, the amount of non- $\mathrm{CO}_{2}$ emissions is calculated by entering the

Table 5 Non- $\mathrm{CO}_{2}$ emission factors of combined cycle power plant in this study

\begin{tabular}{|c|c|c|c|c|c|}
\hline & \multirow[t]{2}{*}{ Fuel type } & \multirow[t]{2}{*}{ Combustion technique/capacity } & \multicolumn{2}{|c|}{ Emission factor $(\mathrm{kg} / \mathrm{TJ})$} & \multirow[t]{2}{*}{ Remarks } \\
\hline & & & $\mathrm{CH}_{4}$ & $\mathrm{~N}_{2} \mathrm{O}$ & \\
\hline This study & LNG & Combined cycle & 0.82 & 0.65 & Average of 8 facilities \\
\hline 2006 IPCC G/L ${ }^{\mathrm{a}}$ & LNG & Combined cycle & 1 & 3 & \\
\hline $2006 \mathrm{IPCC}$ G/L ${ }^{b}$ & LNG & - & $1(0.3-3)$ & $0.1(0.03-0.3)$ & \\
\hline \multirow[t]{2}{*}{ FINLAND NIR ${ }^{\mathrm{c}}$} & LNG & Gas turbine (including GTCC) $/>5 \mathrm{MW}$ & 1 & 1 & \\
\hline & & Gas turbine (including GTCC) $/<5 \mathrm{MW}$ & 3 & 1 & \\
\hline Japan NIR ${ }^{\mathrm{d}}$ & Gaseous fuel & Gas turbine (including GTCC) & 0.75 & 0.54 & Average of 12 facilities \\
\hline
\end{tabular}

GTCC gas-fired turbine combined cycle

a 2006 IPCC G/L—representative technology-specific default emission factor in utility source

${ }^{\mathrm{b}} 2006$ IPCC G/L — default emission factors by only fuel type

${ }^{\mathrm{c}}$ Greenhouse gas emissions in Finland 1990-2005 (Statistics Finland 2007) - mission factors of stationary sources

${ }^{\mathrm{d}}$ National Greenhouse Gas Inventory Report of Japan (2007) — emission factors for different fuel and furnaces 


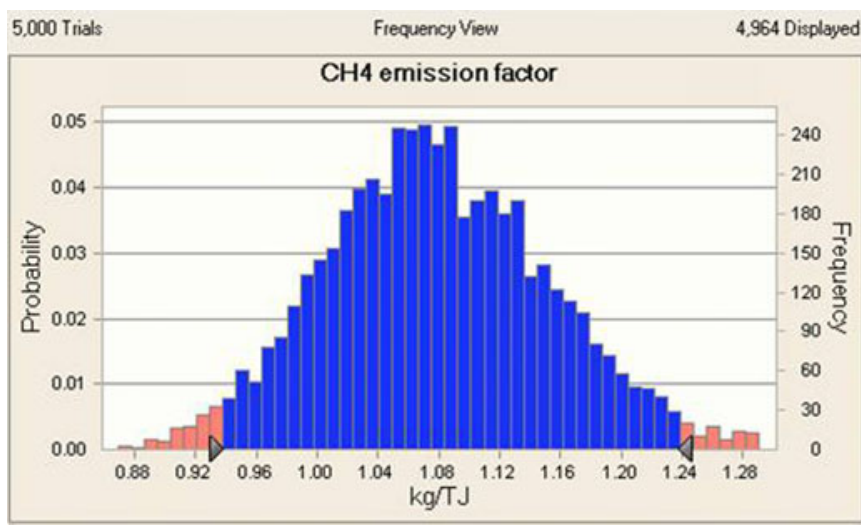

Fig. 3 Results of simulation for non-CO2 emission factors in this study

heating value of the fuel after analyzing it, and as a result, the non- $\mathrm{CO}_{2}$ emission factor is calculated.

\section{Result and discussion}

\section{Non- $\mathrm{CO}_{2}$ emission characteristics}

Table 4 shows the non- $\mathrm{CO}_{2}$ emission concentrations of each power plant. The samples were collected from the units of the power plants under operation and 15 samples were taken, on average, from each stack.

The average $\mathrm{CH}_{4}$ concentration was $1.42-2.33$ and $0.27-$ $0.55 \mathrm{ppm}$ for $\mathrm{N}_{2} \mathrm{O}$. This is because each power plant has different operational conditions; the amount of fuel consumed per the amount of electricity generated and the emission flux of exhaust gas. For this paper, we researched the operational conditions, the amount of fuel consumed, and the emission flux at each time when samples were taken to calculate the non$\mathrm{CO}_{2}$ emission factor of combined cycle power plants in Korea.

Results of non- $\mathrm{CO}_{2}$ emission factor calculations

This paper first identified the characteristics of LNG fuel to calculate the non- $\mathrm{CO}_{2}$ emission factor of a combined cycle power plant that uses LNG as fuel. In order to apply non- $\mathrm{CO}_{2}$ emission concentrations and combustion conditions of exhaust gas, we used the amount of fuel consumed, and emission flux

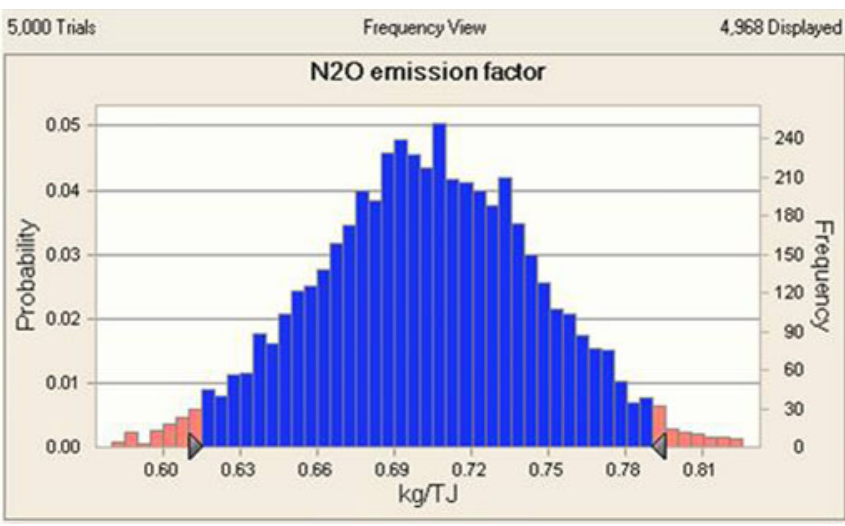

of TMS and the amount of electricity generated each time samples were taken to calculate the non- $\mathrm{CO}_{2}$ emission factor of each power plant. As shown in Table 5, which presents emission factors calculated in the research, the $\mathrm{CH}_{4}$ emission factor is $0.82 \mathrm{~kg} / \mathrm{TJ}$. This value was $18 \%$ lower than the technology-specific $\mathrm{CH}_{4}$ emission factor of "combined cycle power plant using LNG as an energy source", as IPCC suggests. In addition, the default emission factor of first fuel-based (tier 1 method of calculating emission amount) LNG suggested by the IPCC is $1 \mathrm{~kg} / \mathrm{TJ}$. The $\mathrm{CH}_{4}$ emission factor of this study is within the rage of the IPCC emission factor $(0.3-3.0 \mathrm{~kg} / \mathrm{TJ})$. Japan researched 11 power plants to calculate the $\mathrm{CH}_{4}$ emission factor of its gas-fired turbine combined cycle (GTCC) power plants, and uses the average value of each power plant as a representative value. The $\mathrm{CH}_{4}$ emission factor of GTCC power plants in Japan was $0.75 \mathrm{~kg} / \mathrm{TJ}$ (the emission factor of our research was $8 \%$ higher). Finland's case suggests different emission factors depending on the capacity of the GTCC power plant, using LNG as an energy source. The $\mathrm{CH}_{4}$ emission factor of a small sized GTCC power plant under the capacity of $5 \mathrm{MW}$ is $3 \mathrm{~kg} / \mathrm{TJ}$, and that of a GTCC power plant over $5 \mathrm{MW}$ is $1 \mathrm{~kg} / \mathrm{TJ}$, which indicates that non- $\mathrm{CO}_{2}$ emissions can be affected by the size of the facility.

The $\mathrm{N}_{2} \mathrm{O}$ emission factor of this study is $0.65 \mathrm{~kg} / \mathrm{TJ}$. This value is far lower than the technology-specific $\mathrm{N}_{2} \mathrm{O}$ emission factor of "combined cycle power plant using LNG as energy source", as suggested by IPCC. However, the value is more than six times higher than the $\mathrm{N}_{2} \mathrm{O}$ basic emission factor of the
Table 6 Uncertainty range of non- $\mathrm{CO}_{2}$ emission factors estimated in this study (unit: percentage)

\begin{tabular}{lllllll}
\hline & $\mathrm{CH}_{4}$ & & \multicolumn{2}{c}{$\mathrm{N}_{2} \mathrm{O}$} & \\
\cline { 2 - 3 } \cline { 5 - 6 } Combined cycle power plant & Distribution & Range & & $\mathrm{N}_{2} \mathrm{O}$ & Range \\
\hline IPCC & - & $50-150$ & & - & Oder of magnitude \\
Finland & Beta & $-75-10$ & & Beta & -75 to 10 \\
This study & Normal & $-12.96-13.89$ & & Normal & -11.43 to 12.86 \\
\hline
\end{tabular}


first fuel-based (tier 1 method of calculating emission amount) LNG suggested by IPCC. The difference indicated that non$\mathrm{CO}_{2}$ emissions change overwhelmingly by combustion technology, which is grounds for establishing country-specific or technology-specific emission factors. Japan researched 12 power plants to calculate the $\mathrm{N}_{2} \mathrm{O}$ emission factor of its GTCC power plants and uses $0.54 \mathrm{~kg} / \mathrm{TJ}$, the average value, as a country-specific emission factor. The value is $1 / 6$ of the IPCC emission factor (combined cycle) and about $20 \%$ lower than that of this study. In Finland's case, the $\mathrm{N}_{2} \mathrm{O}$ emission factor of all GTCC power plants was $1 \mathrm{~kg} / \mathrm{TJ}$, which is $1 / 3$ of the IPCC emission factor (combined cycle) and about $54 \%$ higher than that of this study.

Analyzing the measurement uncertainty of the non- $\mathrm{CO}_{2}$ emission factor

This paper assessed uncertainty with the non- $\mathrm{CO}_{2}$ emission factor of GTCC power plants using LNG as an energy source with Monte-Carlo simulation. The assessment was conducted in accordance with the 2006 IPCC G/L and probability distributions of $\mathrm{CH}_{4}$ and $\mathrm{N}_{2} \mathrm{O}$ emission factors are selected as normal distribution because its $p$ value was the highest among lognormal, gamma, uniform distribution. Figure 3 represents the simulation result of 5,000 repetitive analyses.

Table 6 shows the non- $\mathrm{CO}_{2}$ greenhouse gas emission factor and measurement uncertainty of GTCC power plants. The emission factor of $\mathrm{CH}_{4}$ is $0.82 \mathrm{~kg} / \mathrm{TJ}$ and the lower and upper limits are set at $0.71 \mathrm{~kg} / \mathrm{TJ}$ and $0.93 \mathrm{~kg} / \mathrm{TJ}$, respectively, with a $95 \%$ confidence interval. In short, the uncertainty range of the $\mathrm{CH}_{4}$ emission factor is -12.96 to $+13.89 \%$.

The average value of the $\mathrm{N}_{2} \mathrm{O}$ emission factor is $0.65 \mathrm{~kg} /$ $\mathrm{TJ}$ and the lower and upper limits are 0.58 and $0.73 \mathrm{~kg} / \mathrm{TJ}$, respectively, at a $95 \%$ confidence interval. The uncertainty of the $\mathrm{N}_{2} \mathrm{O}$ emission factor is $-11.43 \%$ to $+12.86 \%$.

\section{Conclusion}

The results of the non- $\mathrm{CO}_{2}$ concentration in exhaust gas revealed that the average emission concentration of $\mathrm{CH}_{4}$ and $\mathrm{N}_{2} \mathrm{O}$ was 1.78 and $0.53 \mathrm{ppm}$, while the emission factors of $\mathrm{CH}_{4}$ and $\mathrm{N}_{2} \mathrm{O}$ calculated from non- $\mathrm{CO}_{2}$ concentration analysis were 0.82 and $0.65 \mathrm{~kg} / \mathrm{TJ}$, respectively.

The $\mathrm{CH}_{4}$ emission factor was $18 \%$ lower than the technology-specific emission factor suggested by the IPCC. However, it was within the emission factor range $(0.3-3 \mathrm{~kg} / \mathrm{TJ})$ of the fuel-based LNG. In comparison with other countries, the emission factor of this study was $8 \%$ higher than that of Japan's GTCC power plant and about $22 \%$ lower than the emission factor of GTCC power plant in Finland with a capacity of more than $5 \mathrm{MW}$. On the other hand, the $\mathrm{N}_{2} \mathrm{O}$ emission factor was much lower than the technology-specific $\mathrm{N}_{2} \mathrm{O}$ emission factor suggested by the IPCC for combined cycle power plant using LNG as an energy source. But it was more than six times higher than the $\mathrm{N}_{2} \mathrm{O}$ emission factor of the fuel-based LNG suggested by the IPCC. In Japan's case, the $\mathrm{N}_{2} \mathrm{O}$ emission factor of a GTCC power plant was $0.54 \mathrm{~kg} / \mathrm{TJ}$, and the emission factor of our study was $20 \%$ higher than that. Meanwhile, the $\mathrm{N}_{2} \mathrm{O}$ emission factor of a GTCC power plant in Finland was $54 \%$ higher than that of our research. And the ranges of uncertainty for $\mathrm{CH}_{4}$ and $\mathrm{N}_{2} \mathrm{O}$ were between -12.96 and $+13.89 \%$, and -11.43 and $+12.86 \%$ respectively, which is significantly lower than uncertainties presented by IPCC. These differences of emission characteristics and precision of emission factors show us that non- $\mathrm{CO}_{2}$ emissions mainly depend on combustion technology, and there is a visible need for establishing country-specific or technology-specific emission factors. And these factors may lead to set up more reliable national greenhouse gas inventory following bottom up approach.

In order to calculate the exact amount of greenhouse gas emissions and set highly reliable greenhouse gas abatement goals, researches on various fuel and energy consuming facilities is needed to develop country-specific emission factors. Furthermore, for Korea to lead international negotiations (such as the Climate Change Convention), research should continue to set up accurate country-specific emission factors, which are used as an indicator in comparing and assessing the amount of greenhouse gas emissions and reduction.

Acknowledgments This work was supported by the Human Resources Development of the Korea Institute of Energy Technology Evaluation and Planning (KETEP) grant funded by the Korea government Ministry of Knowledge Economy (no. 20100092).

Open Access This article is distributed under the terms of the Creative Commons Attribution License which permits any use, distribution, and reproduction in any medium, provided the original author(s) and the source are credited.

\section{References}

IPCC (Intergovernmental Panel on Climate Change) (2006) Intergovernmental Panel on Climate Change Guidelines for National Greenhouse Gas Inventories

Korea Institute for International Economic Policy (2009) International trends in post-2012 climate change negotiations and their implications

Ministry of Environment (2010) The Establishment of traceback model for low carbon society road map

Ministry of the Environment Japan (2007) National greenhouse gas inventory report of Japan

Quick JC, Glick DC (2000) Carbon dioxide from coal combustion: variation with rank of US coal. Fuel 79:803-812

Statistics Finland (2007) Greenhouse gas emissions in Finland 1990 2005 
The Ministry of Environment (2004) Experiments for the examination of air pollutants

The Ministry of Environment (2011) Announcement. 10 Oct 2011

UNFCCC (United Nations Framework Convention on Climate Change) (2009) Copenhagen Accord

US EPA (2001) Promulgated method 4 and method 18 (http://www. epa.gov/ttn/emc/)
Wight GD (1994) Fundamentals of air sampling. Lewis, New York, pp 135-184

WRI/WBCSD (2005) Calculating tool for direct emissions from stationary combustion version 3.0

Youngsung C, Young Dae J, Soonae P (2006) Factors affecting greenhouse gas emissions in the electricity sector. Environ Policy 14:215-236, No. 1 